\title{
ANALYSIS OF SUFISM MISSION REPRESENTATIVES ACTIVITY OF CENTRAL ASIA IN THE XVI CENTURY BY THE SAMPLE OF WORK "LAMAHOT"
}

\author{
A. K. Kandakharov
}

Doctoral applicant

Navoi State Pedagogical Institute

Navoi, Uzbekistan

\begin{abstract}
Sufism mission, which is an inseparable part of Islam religion is highly considered in developing Islamic knowledge, consolidate, popularize the idea of justice, conscience, and perfectness in the life of society. Coming to the XVI century Sufism mission continued developing in the whole Islamic world, especially in Central Asia and began to be of great importance in social - political and spiritual life of the country. This article is discussed on the Sufism mission position of Central Asia in XVI century, meaning, point and the role in the social- political life of government and society. Also, analysis of Sufism mission representatives' activity of central Asia in the xvi century by the sample of one of the rare manuscripts "Lamahot min nafahot ul-quds" (Good memories in the holy).

Keywords: Sufism; mission; silsila (system, chain, dynasty); manuscript sources; fikh (subject about religious rules); history; tafsir (meaning of text); legend about prophet; sheik; divine relative; social-political life.
\end{abstract}

Being systematic development, $\mathrm{Su}-$ fism mission appeared in Islamic world initially in the middle of the VIII century, in the territories as Kufa, Bagdad, Basra and Egypt where Islam religion was spread widely and in the XI-XII centuries Independent Yassaviya, Kubraviya later in the XIV century Khojagon- Nakshbandiya missions came into Central Asia [8, p. 5]. At first Sufism mission was used as asceticism (secluded, wise). After the death of Prophet Muhammad, there was division among the Muslims group and in the time of Khalifa Usman (646-656) high interest in wealth was in full swing. When it was time of Ummaviy Khalifa, yearning for gathering treasure, interest in gold-silver, luxurious decoration and castle ornaments intensified. This condition became the reason for dissatisfaction of the convinced people who preferred following religious rules to any world works and richness. Among them there were also (muhaddis) writers of legend about Prophet Muhammad, (sahoba) wise people who were poor and not interested in luxurious houses and property. While a part of them defended religion and intended to open struggle, the second part of them began to devote themselves to praying forever avoiding social activity entirely and propagandizing the idea of monomania as a sign of dissatisfaction against the riches behaviors and people of castle aiming 
contentment and satisfaction ("zuhd" originated from "zohid") [4, p. 10].

In the society of Central Asia in the Middle Ages Sufism missions became apparent as an ideological factor, effected traditions and customs strongly. Being more complex and multifunctional at the same time this knowledge was faced to some changes in the result of social-political points of various periods.

Sufism mission of Central Asia is connected with the name of famous scholar Sheikh Khoja Yusuf Hamadony (1048-1141). His disciples Khoja Akhmad Yassaviy and Abdukhalik Gijdivony (died in 1179) founded two independent missions later: YassaviyaJahriya and Khojagon- Nakshbandiya missions. In Khorazm there appeared independently Kubraviya missions of Najmiddin Kubro (1145-1221) who was famous with a title of "valiytarosh" (means the people who can predict the future) [10, p. 10].

These missions spread widely in Central Asia and had a stable status. Also, Shiekhs who belonged to Kodiriya mission and their activities in Central Asia were talked about in the works and researches of the scientists who made research on Sufism mission. This Sufism mission was founded by Abdulkodir Jilony (1077-1166) in Iraq in XII century, according to this mission there was no separated way indicated, which was considered compulsory for murshids (the followers of Sufism reperesentativs). According to their points they belong to Sunnis and they consisted of reading order of suras and ayats, adaption of divine ideas, hymns related to religious murhids [9, p. 105]. Coming to the XVI century Yassaviya mission increased in the top in Central Asia. In this period many famous representatives and fellows of this mission appeared. It is known that Yassaviya mission murshids (fellows) followed the strict rules as well as shariat, truth, mission which are included in the general status of all missions. Moreover, in the practice of this mission pronouncing kalima and duas (from Koran) in loud voice, that is in Jahriy way was considerable. That is why this mission is called as "Yassaviya- jahriya".

As it is in other missions, in Yassaviya mission many manuals and works were written on the purpose of propagandizing divine truth as well as planning the duties and basis of pirmurshidies (divine scholars). One of the rare manuscripts "Lamahot min nafahot ul-kuddus" (Moments of Sacred flavors) written by Hazrat Olim Shiekh in Hijry 1033, Milady 1624, several copies of manuscript are kept [6, p. 288]. This work is considered as one of the main manuscripts which informs much about life and activities of Yassaviya Sheikhs, also important information about life an activities of Sheikh Khudoydod and Kosim Sheikh Azizon, who were the most famous representatives of Sufusm in XVI century, as well as the facts which don't exist in other sources related to the large parts in Yassaviya mission. The author of the work Hazrat Olim Sheikh was one of the close religious relatives too. In the work of "Tarikhi tom" by Sharafuddin Rokimi this source was 
considered reliable, in "Kitabi Lamahot" (Book of Lamahot) Olim Sheikh (kuddusa sirruhu) said that: "that Great Person (Sheikh Khudaydod) wrote his status and titles right" [7, p. 85].

The work was called shortly as "Lamahot" in large scientific community. The author of the work belonged to the alavies, mother side (that is Ali's children of other wives besides Bibi Fatima); father side, to Abu Bakr Siddik [6, p. 3]. Author, the scientist on Sufism E. Karimov reminded in his researches that it is the one of the important sources about life and activities of mission representatives as well as expresses their ideas, history, and superiority of Yassaviya mission in "Lamahot" [3, p. 21].

Mukhammad Olim Sheikh was born in 1564 in Tashkent city in the territory of Movarounnakhr in the period of struggles were strength. In 1582, after Tashkent city had been occupied by shaybany Abdullakhan II the father of Olim Sheikh moved to the Aliabad neighborhood in Samarkand with his family. In "Hujjat ul-zokirin" there was given about this as: "... when there was struggle in Tashkent region they - Mumin Shaeikh, father of Olim Sheikh moved to the Aliabad neighborhood and there they lived with Mavlono Ismatulloh [6, p. 28].

Olim Sheikh gave information also about his ancestors, close relatives in "Lamahot" and expressed it in the following steps: "Mukhammad Olim Siddiky Alaviy inb Mumin Sheikh, ibn Dervish Sheikh, ibn Sheikh Khovand (his nick is Sarimast), ibn Fatkhulla
Shaeikh, ibn Sheikh Tojiddin, ibn Sheikh Aloviddin, ibn Kutb al-aktob Zaynuddin (Kuhi Orifon), ibn Shaeikhulislom Abu Hafe Shakhobuddin Sukhravardiy joined to Abu Bakr Siddik by the thirteen means. Mother side grandfather of Olim Sheikh is Hofiz Tashkandi (Hofiz Kukhaki (died in 1584) - famous scientist and scholar lived in XVI. He was the grandson of Ali Kushchi)". "According to the author's idea he was generation of Sufi Mukhammad Donishman. Also, Sufi Mukhammad joined to the posterity of Abu Bakr Siddik" [6, p. 144]. Moreover, Olim Sheikh talked about Hofiz Tashkandy respectively in his work.

Given above information shows that Olim Sheikh Azizkhan had great prestige in times of ashtarkhaniy ruler Imomkulikhan (1611-1642), as well as he was active in social, political, economical, and cultural spheres. Olim Sheikh Azizkhan tried to have close relationship with Sheikh Khudoydod and as it is written in the sources he married to his granddaughter [6, p. 101].

Olim Sheikh Azizkhan acted as a facilitator (murshid) of mission both theoretically and practically. He wrote works related to science of fikh, mission as well as taught a lot of apprentices. In particular, his apprentices such as Nugay Father, Mavlono Okhund, Khoja Abdurashid, Khoja Fatkhulloh Azizagiy, Muhammad Solih Urganjiy, Mavlono Usmon, Mavlono Sayyid Mukhammad Sharif, Khoja Fazl, Mavlono Husayn Farokhiy, Husayn Sheikh Azizkhan, Abduraffi Azizkhan Turkistoniy, Mavlono Mukhammad Otroriy, Mavlono 
Ibrohim Turkistoniy, Mukhammad Amin Oratepagiy were mentioned in the sources [2, p. 144]. Olim Sheikh Azizkhan was an important circle in the process of Yassaviy mission, after that a lot of famous representatives of this mission were brought up in the central Asia who played an essential role in country's social-political life .

Besides, works mentioned above Olim Sheikh Azizkhan wrote also „Risolai manokib” (honour), it was included in Sank-Petersburg copy of „Lamohot" [1, p. 282]. In the introductory paragraph of the work author admitted that he intended to write this work with the spiritual sign of Khoja Akhmad Yassaviy. In his dream he saw himself sitting on the shoulder of Akhmad Yassaviy and saying about education. Right that time one of the wise persons of that time reprimanded him: "Hey bad behaved!" but Akhmad Yassaviy said: „All right he can say about enlighten sitting on our shoulder". After this event author intended to write work for people who were interested: “Khoja Akhmad Yassviy's ashobs (followers), about their havorik habits (strong religious habits) which are enough until kiyomat (the end of the world)". As well as, in the end of work Olim Sheikh Azizkhan mentioned that he had received sign from prophet to write a book about Yassaviy sheiks $[6$, p. 7]. This work has hagiographic genre and structure. In particular, Miklukho Maklay also admitted: „The work „Lamahot" doesn't differ from hagiographic works. It can be compared with the work of ,Rashohot aynul-hayot" which was devoted to the life of representatives of Khoja Nakshbandiy mission [5, p. 133].

The work of ,Lamahot" consist of prologue and two chapters. The first chapter is named „About advantages of remembering religious rules in Jahr way (in loud voice)". There given verses of the Koran and legends about prophet Muhammad and evidences from such works such as „Koran Karim“, „Al-Kashshof“, „Jome'-asSahih”, „Fattoi Tatarkhoniya”, „Mushkoti sharif”.

Second chapter dedicated to „Narration of habits and wills of Yassaviya process members". In this part stories that are related to Yassaviya representatives who lived since the time of Khoja Akhmad Yasaviy till the time of author. In particular, there are data about life and activities of sheiks who were related to mentioned process. Author acquainted with most of them who were contemporary to him.

It is climbed that Olim Sheikh 's work was written to pursue two aims. Particularly, the first aim is to proof main point of jahriy zikr (remembering religious rules remembering religious rules in loud voice) with scientific evidences and to show its positive sides. The second is to narrate widely the statuses and miracles of wises of Yassaviya emission and to say their sacred words (kalimoti qudsiya) related to $\mathrm{Su}-$ fism [6, p. 4].

There was given broad information about pir and murshids (religious facilitators), the essence and history of other Sufism, as well as yassaviya. Also it gives good opportunity to reestablish ancient toponim names of historical 
places existed in Central Asia. Stories and myths used in work are proved by prophets and confirmed by author's own point of view. Traditionally, the source tells about the life and biography of the founder of Yassaviya Khodja Akhmat Yassaviy. The author finishes with stories about his sacred generation darvish Sheikh, Mumin Sheikh and his holy masters Kosim Sheikh and Pirim Sheikh. The life of Sheikh Khudoydod Vali and his murids is totally revealed than other members of Sufism. This signifies Sheikh Khudoydod Vali's importance on that time, additionally Olim Sheikh Azizon considers him as his master of Sufism. Besides, talks held among famous leader of KhojagonNaqshbandiya, Sheikh Khudoydod Vali and the member of Makhdumi Azam Dakhbediy Kubroviya Sheikh maxdumi Khorazmiy are specially highlightened. Some interesting myths related to Akhmad Yassaviy's Sufism are given in "Lamahot" that rarely could be found in other sources. For instance, those who not admitted Sufism and not endured in some steps were strictly prohibited by Akhmad Yassaviy [6, p. 3]. Because it made bad influence on murids (religious relatives) and Murshid's spiritual view that taking part in talks.

After the unit devoted to Akhmad Yassayiy, the author renames the members of suluki in the stories and myths related to the members of yassaviya: father Khakim, Sufiy Mohammed Wise, Kubbi Khodja, Bobo Mochin, father Zangi, father Uzun Khasan, father Sayid, father Badr, fa- ther Sadr, father Khodja Ismail, father Khodja Ishok and etc. As well as the author gives important information about fellow Sheikhs such as Mavlono Ismatulloh, Sheikh Jaloliddin, Sheikh Khudoydod, Darvish Sheikh, Mavlono Khushmuhammad Azizon, Tokhir Mokhammed Sheikh, Mumin Mokhammed Sheikh, Kanbar Sheikh, Mavlono Vali Kuhizarriniy, Kasim Sheikh, Pirim Sheikh, Fozil Sheikh.

The work deals with the main point and requirements of Sufism as fakr (one of the Sufism habits), tavakkul (to feel all good or bad happenings from the God, to belief the God), tafakkur (idea,discuss), irodat (ray of love,intention), futuvvat (generosity), ishk (Love- strong love in Sufism), tasfiya (clearing, becoming pure), zikr (conversation, reminding name of Allah without stopping), riyosat (getting physical tortured, suffer, keeping down greediness, following requirements of Sharia and Sufism), ilmi laduniy (divine knowledge given by Allah), fano (disappearing, being transient, destroyed the thing by Sufism), tavhid (believing in God as One scientifically), bako (permanency, prolongation) that deeply investigated and sample ideas given by Sufism masters.

The book comprises very essential historical facts about treatments of Sheikhs and rulers, Sheikhs and beggars that assists to observe socialpolitical life of the members of Yassavia. Especially the role of Akhmad Yassaviy for Shakhbek (Shaybaniykhan) in being the leader of Mavaraunnahr, special altitude of Shaybaniykhan to Akhmad Yassaviy, events 
and the facts about mutual relationship of yassavia Sheikhs and rulers such as Mirza Babur, Abulkharkhan, Ubaydullakhan, Javanmard Alikhan, SultanAkhmad Mirza, Amir Baki (Baki Tarkhan - the ruler of Bukhara), Sultan Kistankara, Baba Sultan, Shakim Kurchu, Barakkhan (Navruz Akhmad), Pirmukhammad, Iskandarkhan, Abdullakhan II, Abdullatifkhan revealed deeply to be considered as precious facts for scientists [6, p. 244]. The myths related to famous Sheikhs and sufiys,servants,sahobas,prophets as well as the sample works by Kamal Khujandiy, Amir Khusayniy, Makhdumi Azam Akhmad Kosoniy,Abdurakhman Jamiy, Khadja Ubaydullakh Akhrar, Fakhriddin Irakiy, Shakhabiddin Suhravardiy, Mohammed Nassoj, Abdukadir Gilaniy, Master Jalaliddin Rumiy, Farididdin Attar are given in the work of Olim Sheikh. Historical events connected with well-known scientists such as Amir Kulal, Khadja Bahauddin Nakshband, khadja Mohammed Parsa, Holy Vaiz Kashifiy, Holy Khalil Karakuliy, Kazikhan Abdullakhan, Holy Isfakhaniy, Khadja Abdushahid, holy Mustafa Rumiy, Holy Abdullakh Toshkandiy, Holy Mirak are revealed in the work. Besides, important facts about Nakshbandiya Sheikhs and other members of Sufism can be found in the work. The author points out treatments of father Zangi-Najmiddin $\mathrm{Ku}-$ bro,Father Zangi-Kadja Ahror, Father Sayid-Bahauddin Nakshband, Father Izmail- Kadja Ahror, Sheikh KHadimKadja Ahror and tries to reveal the original meetings held by them. This is talk held by Sheikh Hudaydod and the member of nakshbandiya Sufism Mahdumi Azam Dakhbediy: "My dear, you should know these holies were close in all meanings. They say, once Holy Khadja Dakhbed went to his motherland Akhsi with his friends and servants. It was spring time. They stopped in Gazira (Samarkand Region). Holy Azizon(Sheikh Khudoydod)went to his place in order to invite him to his place. But Holy Makhdumi Azam refused because of food of hundred servants and horses. Then two holies said goodbye, but Holy Azizon on his way home said to his servants: We'll make him visit our house "It'll rain this night. They have to come to our place. At last they moved to his accommodation. Holy Azizon welcomed all guests and they prayed for God, Holy Hazrati Azizon told great words and Holy Mavlono listened to him attentively. Then they said farewell to each other and went on their way" [6, p. 99]. Moreover, members of Yessavia and Khodjagon Nakshbandia were in good relationship with each other. The author tried to show close relationship among these 3 Sufism directions. It's known that well-known member of Nakshbandia Makhdumi Azam, notorious member of Kubrovia Sheikh Makhdumi Khorazmiy and Holy of Yassavia Sheikh Khudaydod Vali lived at the same period. They crested friendly atmosphere and leaded hot discussions. This served to build bridges among these Sufism directions. Talks held by these Sufism directions revealed in the book "Lamahot." They all gathered in meet- 
ings and talked about their own directions. Holy Ibrahim told: "My father was Holy Azizon's servant and lived in Miyankol. Once Holy Azizon came to my father's place. That day Holy Mavlono Khodjagi (Makhdumi Azam) and Holy Sheikh Khusayn Khorazmiy also took visit and conducted hot debates. Afterwards, Sheikh Khusayn Khorazmiy ordered to play the doodle. While he was playing Holy Khorazmiy (dur to Kubrovia Sufism) conducted heaven's dance". These both Holies stood due to the respect of other Sufism directions. Afterwards, Holy Mavlono Khodjagi Makhdumi Azam Dakhbediy (due to Nakshbandia)made speech, others listened to him attentively. Then Holy Azizon Sheikh Khudaydod (due to Yassavia) prayed (zikri arra), two Holies listened to him. That debate went on till afternoon. Kambar Sheikh observed this debate from his prone and called 4forced meeting. Then all Holies said farewell to each other" [6, p. 100].

The author of the book also has relation to these Sufism directions, he lived at the same period with Holy Kasim Sheikh. Thus all information used in the source considered to be true. The book "Lamahot" gives information about not only Yassavia, but also Kubrovia and Nakshbandia, their Sufism stories, the life and work of famous holy sacrets.

This work made a positive effect on the life and work of yassavia Sheikhs. One of the Khalifat's of Olim Sheikh Azizon Khodja Fathullokh enriched his master's work "Lamahot" with his mas- ter's life and work. Then he called it "Takmilayi Lamahot" [5, p. 133-137].

There given complete information about Khodja Akhmad Yassaviy and his Sheikhs, especially was described initial period representatives of Yassavia. Moreover, the author tried to fulfill previous sources by pointing out exact date and place of death yassavia's Sheikhs.

In conclusion, the book "Lamahot" written by Mohammed Olim asSiddikiy considered to be most important historical source for revealing the facts about Yassavia's sheihks lived in 16century in Bukhara, as well as the history of Sufism directions in Central Asia. Historical significance of the work is that there is given valuable facts about Yassavia sheiks and the life of well-known representatives, their participation in social-political, cultural process in Central Asia in 16century. For instance, a lot of historical facts related to Sheikhs lived Lower Zarafshan valley as well as the life and work of holy Sheikhs. Sheikh Khudoydod and Kasim Sheikh deeply highlightened. It should be mentioned, the book "Lamahot" attracts attention for precious facts about altitude of Sheikh-murid, Sheikh-ruler conditions about being Sheikh, the rules of Sufism, facr, fano, ways and secrets of spiritual perfectness.

The book "Lamahot" by Mohammed Olim As-Siddikiy one of the staple sources for keeping Yassavia traditions and investigating the history of this direction. It gives important facts about early members of yassavia up to 
members lived at the beginning of XVII century.

Besides, this describes the portrait of social, economical, political, religious situation of Central Asia in XVXVI centures. In addition, great representatives of yassavia Sheikh Khudoydod Vali and Kasim Sheikh from Karmana, their role in society of Sheybanids are depicted in the book.

The author of the "Lamahot" describes the date of birth and death, the place and cemetery of historical personalities related to Yassavia Sufism. Moreover, there given ancient names of mountains and valley of Central Asia that appreciated as valuable source for toponymy.

This can be concluded as Holy Olim Sheikh Azizon and notorious representatives of yassavia and other Sufism directions lived in Central Asia were important chains to rule economical-political life of that period.

\section{Bibliography}

1. Akimushkin O. F., Kushev V. V and others.,Persian and Tajik manuscript of the Institute of Asian Public of AN SSR, red. - Moscow, 1964.

2. Xasanov N. Mukhammad Olim Siddikiy and about his work "Lamahot min nafahoti-l-kuds". // Knowledge of Imam al-Bukhariy. - 2006. - № 3.

3. Karimov E. E. Yassaviya and Khodjagon Nakshbandiya: real and imaginary history. - Tashkent : Uzbekistan, 2000.

4. Komilov N. Mission. New Edition. Tashkent : Movarounnahr, 2009.

5. Miklukho N. D. Description of Persian and Tajik Manuscripts. Vol. 2. - M., 1961.

6. Mohammed Olim Sheikh Azizon. Lamahot. Ideas of Preceptors in Yassaviya Sufism. K. Kattaev and A.Narzullaev from Farsi, Samarkand, 2007. Mukhammad al-Olim as-Sodik as-Alaviy-Olim shikh. Lamahot min nafahot ul-kuddus. UzAS the centre of manuscripts of Institute of Orientation. Inb. - № 495, 2671. $288 \mathrm{p}$.

7. Sharafuddin Rokimi.tarihi tomm. - Tashkent : Ma'naviyat, 1998.

8. Usman O. Seven Scholars of Bukharai Sharif. - Tashkent : TashSEI publication, 2003.

9. Usman Turor. History of Sufism. H. Khasan translation from Turkish language. - Tashkent : Istiklol, 1999.

10. Yulduzkhadjaev Kh. The role of Musokhan Dahbediy in the development of Nakshbandiya - Mujaddidya mission (XVIII century). Autoreference. Candidate of History Science. - Tashkent: 2008.

(C) Kandakharov A. K., 2017. 